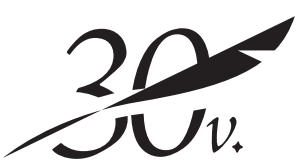

Tiedotus -

T U T KIMUS

KIELEN RAKENNUSTELINEILLÄ:

\title{
KIELELLISEN JA YHTEISKUNNALLISEN KÄÄNTEEN MERKITYS
}

\begin{abstract}
Kielellinen käänne on ihmis- ja ybteiskuntatieteissä usein käytetty käsite. Harvoin sitä kuitenkaan määritellä̈n tai pohditaan sen enempä̈. Sosiaalisen konstruktionismin viitekebykseen perustuva kielellinen käänne sekä kuvaa, muokkaa että rakentaa niin teorian kuin käytännönkin tasolla kielen ybteiskunnallistumista ja ybteiskunnan kielellistymistä. Kirjoituksessa kartoitetaan käsitteen historiallista syntyä, sen merkitystä suomalaisessa ybteiskunnallisessa ja humanistisessa tutkimuksessa sekä ongelmia, joita käsitteen soveltamisessa voidaan näbdä, ja mahdollisuuksia, joita se tarjoaa. Näkemyksemme mukaan kieli voidaan ajatella resurssina, joka subteutuu makrorakenteisin, ja tutkija voi tietyn tilanteen kielenkäyttöä yksityiskohtaisesti tarkastelemalla tutkia niin kielenkäytön mikrotasoa kuin myös ympäröivän yhteiskunnan makrotasoa. Tutkimuksessa tämä yksityiskohtainen analyysi avaa näkökulman, jonka avulla voidaan pobtia, kuvata ja teoretisoida kielten buokoisia eroja ja rajoja, kielenkäyttäjän toimintaa ja valintoja, kielen kantamia valtarakenteita sekä kielenkäytön ja ympäröivän ybteiskunnan subdetta. Kielen resurssiluonne mahdollistaa sen, että erilaiset humanistiset ja ybteiskuntatieteelliset tutkimusalat voivat todellisesti byödyttää ja byödyntää toisiaan.
\end{abstract}

Kielellinen käänne on yksi käytetyimmistä, mutta samalla vähiten määritellyistä käsitteistä ihmis- ja yhteiskuntatieteissä. Se viittaa merkittävään humanistisen ja yhteiskunnallisen tutkimuksen murrokseen, jonka seurauksena kieli nousi tutkimuksen keskeiseksi kohteeksi ja kysymyksenasettelun lähtökohdaksi. Niin teorian kuin käytännönkin tasolla kielellinen käänne sekä kuvaa, muokkaa että rakentaa kielen yhteiskunnallistumista ja yhteiskunnan kielellistymistä (ks. Bergmann 1950b, 484). ${ }^{2}$ Käsitteen taustalla on sosiaalisen konstruktionismin tutkimuksellinen viitekehys, jonka mukaan todellisuutemme rakentuu kielellisessä (ja muussa semioottisessa) vuorovaikutuksessa niin ettei todellisuutta voida tavoittaa kuin käsitteellisen ja kielellisen viitekehyksen kautta (ks. Dallmayr \& McCarthy 1977, 7; Berger \& Luckmann 1994/1966).

On helppo ymmärtää käsitteen itsepintaista määrittelemättömyyttä, kun katsoo kielellistä käännettä soveltavien analyyttis-filosofisten, kulttuuristen ja kielitieteellisten lähestymistapojen sekä niiden edustajien kirjoa: venäläinen formalismi (Bahtin 1981; Šklovski 2001/1917), strukturalismi (Barthes
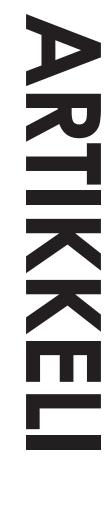
1994/1957; Genette 1966-1972), jälkistrukturalismi (Derrida 1978/1967; Foucault 2005/1969), feministinen kritiikki (Irigaray 1996/1984; Kristeva 1992/1988), jälkikoloniaalinen kritiikki (Said 1978; Spivak 1987), artikulaatioteoria (Hall 1992/1986; Grossberg 1995), semantiikka (Lyons 1977), puheaktiteoria (Searle 1969), etnometodologia (Garfinkel 1967), keskustelunanalyysi (Sacks 1992) tai kirjallisuustieteessä tulkintayhteisöt (Fish 1980). ${ }^{3}$ Kyse on siis hajanaisesta ja monialaisesta joukosta teoreettisia suuntauksia, joita yhdistää "vetoaminen kieleen, diskurssiin tai kielellisen representaation muotoihin filosofian tiedon ja totuuden etsinnän äärimmäisenä pisteenä” (Norris 1995, 492).

Vaikka edellä mainitun käsitteen käänteenomaisuus voikin antaa vaikutelman siitä, että se olisi ollut äkillinen, on se kuitenkin merkinnyt pitkäaikaista prosessia, jonka kuluessa on tapahtunut merkittäviä kokonaisvaltaisia paradigmaattisia muutoksia - eri tieteenaloilla eri aikoina laajuudeltaan vaihtelevasti. Keskeistä tässä muutoksessa on konstruktionistinen ajatus, jonka mukaan todellisuus on sosiaalisesti rakentunut, sekä ajatus, että kieli on todellisuutta keskeisesti muokkaava tekijä. Aiemmin yhteiskunnan ja kulttuurin määrittäjinä pidetyt rakenteet ja prosessit nähdään nyt viestintäyhteisönä pidetyn kulttuurin tuotteina (Iggers 2005/1997, 123). Voimme tuntea todellisuuden vain kielen avulla - jopa niin, ettei kielen (tekstin) ulkopuolella nähdä olevan mitään: "Il n'y a pas d'hors-texte" - ei ole mitään "tekstin ulkopuolista" (Derrida 1978/1967, 227). Käänne ei ole siis kohti kieltä itseään, ikään kuin maailmasta erillisenä, vaan nimenomaan kohti näkemystä, jonka mukaan kieli hallitsee, ylläpitää ja luo todellisuutta (ks. Kuortti 1998, 147-148). Jos esimerkiksi tutkimme yhteiskunnan rakenteita tai prosesseja, tutkimme niitä kielen kautta ja kielen avulla.

Kielellisen (tai lingvistisen) käänteen historia on moninainen, mutta sen nimeämisessä keskeinen virstanpylväs on filosof Richard Rortyn toimittama artikkelikokoelma The linguistic turn: Essays in philosophical method (1967). Juuri sen kautta kielellinen käänne (the linguistic turn) tuli käsitteenä laajemmin käyttöön ja tietoisuuteen. Kirjassa olevassa pitkässä esipuheessaan Rorty mainitsee, että käsitteen olisi luonut Gustav Bergmann. Hän viittaa Bergmannin kirjaan Logic and reality (1964, 177; ks. myös 1959, v), jossa tämä puhuu 1900-luvun alun analyyttisen filosofian metoditietoisuuden kasvusta ja kuvaa sitä juuri käsitteellä "kielellinen käänne”. Jo aiemmin Bergmann (1950a, 472; 1950b, 484) käytti käsitettä kuvaamaan loogisen positivismin kehitystä matemaattisen logiikan suuntaan 1800-luvun puolivälistä alkaen. Tätä ennen käsite ei nähdäksemme ole ollut käytössä. Rorty katsoo itse kuuluvansa pragmaattisen filosofian kielelliseen suuntaukseen.

Antiessentialistina Rorty $(1999,134-135)$ korostaa, ettei ilmiöiden suhteen voida tehdä jaottelua ulkoiseen ja sisäiseen, koska "ei ole olemassa todellisia, ei-relationaalisia ominaisuuksia". Itse kielellisen käänteen ilmiö on nimeään pidemmän historian tuote. Sen juuria voidaan etsiä vaikkapa Ferdinand de Saussuren (1916) strukturalistisesta mallista, Ludwig Wittgensteinin ensin Tractatuksessa (1984/1922) esittämästä kielifilosofisesta pohdinnasta tai hänen näitä ajatuksia kritisoivasta myöhäisemmän kauden kielipeliteoriastaan (1999/1953) tai peirceläisestä semiotiikasta (ks. Peirce 2001). Juuri Wittgensteinia Bergmann (1950a, 472) pitää uuden kielellisen käänteen keskeisenä hahmona. Wittgenstein (1999/1953, § 90, 80-81) kuvaa näkemystään kielel- 
Meistä tuntuu siltä kuin meidän täytyisi katsoa ilmiöitten läpi:

Tutkimuksemme ei kuitenkaan kohdistu ilmiöibin, vaan - kuten voisi sanoa - ilmiöiden 'mahdollisuuksiin'. Toisin sanoen, pysähdymme pohtimaan niiden väitteiden laatua, joita ilmiöistä esitämme. [...] Tarkastelumme on näin kieliopillinen. Tämä tarkastelu luo valoa ongelmaamme raivatessaan pois väärinkäsityksiä. Väärinkäsityksiä, jotka koskevat sanojen käyttöä ja jotka ovat aiheuttaneet muun muassa tietyistä ilmaisumuotojen välisistä analogioista kielemme eri alueilla. - Monet niistä voidaan poistaa korvaamalla ilmaisumuoto toisella; tätä voidaan sanoa ilmaisumuotojemme "analysoimiseksi", sillä tapahtuma muistuttaa toisinaan jonkin purkamista.

Toisaalta voidaan perustellusti väittää, että kieli on ollut merkityksellinen yhteiskuntateorioissa - vaikkapa Antonio Gramscilla - jo ennen strukturalistisen ajattelun syntyä (ks. Ive 1999); ajatellaanpa vaikka kielen merkittävää roolia nationalististen liikkeiden muotoutumisessa (ks. Anderson 2007/1991). Myös Bergmann (1950b, 484) toteaa, että kulttuurin tulo kielitietoisemmaksi on ollut yhteydessä samanaikaiseen ideologiatietoisuuden kasvuun. Vaikka historiallisesti voidaankin osoittaa kielellisen käänteen kehittyneen tietyistä filosofisista lähtökohdista, ei itse käsitteen kuvaama asia ole kuitenkaan samaan tapaan historiallinen. Kieli on (ollut) todellisuutta rakentava silloinkin, kun sitä ei ole sellaisena pidetty.

Kielellisen käänteen ohella nykyisin puhutaan monista muistakin rinnakkaisista ja täydentävistä käänteistä: voidaan puhua niin kulttuurisesta, diskursiivisesta, yhteiskunnallisesta, retorisesta kuin visuaalisestakin käänteestä. Näiden käänteiden käänne-luonne syntyy siitä, että on alettu soveltaa jotakin uutta: uusia näkökulmia, käsitteitä tai menetelmiä, joissa on vaikutteita muilta tutkimusaloilta, kuten kielellisessä käänteessä kielentutkimuksesta.

Kielellisessä käänteessä korostuu kieli vallan muotona (Tompkins 1980, 226). Käänteen taustalla vaikuttaa edellä kuvattu konstruktionistinen näkökulma, jonka mukaan kieli ei ole ajatusten ja viestinnän "puhdas" väline tai läpinäkyvä ikkuna maailmaan tai toisen ajatuksiin, vaan ainesta, jota eri tavoin (tietoisesti ja tiedostamatta) muokkaamalla ja käyttämällä saadaan erilaisia lopputuotoksia. Toisin kuin esimerkiksi formaaleissa näkökulmissa, konstruktiivisessa lähestymistavassa kieli ymmärretään siis käyttäjistään riippuvaiseksi, tilannesidonnaiseksi, seurauksia tuottavaksi ja olennaiseksi osaksi sosiaalista elämäämme. Vaikka juuri kielellinen käänne toi tällaisen funktionaalisen kielikäsityksen voimakkaasti esille, se on ollut kielentutkimuksessa läsnä tai idulla jo kauan.

Vaikutusvaltaisen chomskylaisen transformatiivis-generatiivisen paradigman (esim. Chomsky 1957) rinnalla kulki koko ajan Saussuresta ja Prahan koulukunnasta lähtenyt kiinnostus paroleen ja kielen funktionaalisuuteen. Tätä linjaa vahvisti erityisesti hallidaylainen näkemys kielestä, joka vaikutti Suomessakin jo 1970-luvulla (esim. Halliday 1973). Toinen tärkeä, hieman filosofisempi perusta kielentutkimuksessa löytyy niin sanotusta Sapirin ja Whorfin kieltä koskevasta suhteellisuushypoteesista ja siihen liittyvistä pohdinnoista. ${ }^{4} \mathrm{Kie}$ lellinen suhteellisuushypoteesi koskee kielen ja ajattelun välistä suhdetta ja on yleensä tulkittu siten, että kieli ohjaa sitä, miten ajattelemme ja näemme maailman. Lisäksi hypoteesi sisältää ajatuksen kielen yhteisöllisyydestä ja kulttuu-

Tiedotustutkimus 2008:3 
risidonnaisuudesta: yhteisön tavat käyttää kieltä ohjaavat ajattelemaan ja käyttämään kieltä - tulkitsemaan ja tekemään kielellisiä valintoja - tietyllä tavalla. Kieli ei kuitenkaan ole vankila, mutta asettaa rajoja sille, mitä ja miten voimme ilmaista. (Tarkemmin ks. Leino 2002/1987; Onikki 1998.) Tärkeää kielellisen käänteen kannalta on, että suhteellisuushypoteesi on osaltaan ruokkinut kielen ja kontekstin sekä ajattelun välisten suhteiden pohdintaa 1950-luvulta alkaen. Ajatus kielen monimerkityksisyydestä, tilannesidonnaisuudesta ja kielellisten valintojen suhteesta maailman hahmottamiseen ja representaatioon liittyy tiiviisti kielelliseen käänteeseen ja sen tuomiin näkökulmiin tutkimuksessa. Kieli ei ole peili, joka heijastaa todellisuutta, eikä myöskään paketti, joka kulkee lähettäjältä vastaanottajalle - vaan merkitysjärjestelmä, joka mahdollistaa erilaisten valintojen tekemisen. Nämä valinnat taas ovat suhteessa siihen, kuka kieltä käyttää ja missä sosiokulttuurisessa tilanteessa sitä käytetään.

Konstruktionistisen näkemyksen mukaan tutkimuksen keskeinen tehtävä onkin tarkastella erilaisten todellisuuksien ja tapahtumien merkityksellistämisen tapoja, ehtoja ja seuraamuksia. Kiinnostuksen kohteena ei niinkään ole se, mikä versioista on "totuudellisin" vaan pikemminkin erilaisten versioiden tilanteinen painoarvo: millainen versio on tiettynä aikana vallalla, mikä marginaalissa tai puuttuu kokonaan. Siten esimerkiksi kolonisoitujen kansojen oikeuksiin tai naisen asemaan liittyvät kysymykset ovat nousseet esiin eri aikoina eri paikoissa eri tavoin. Kielen ja vallan välisen suhteen tarkastelu vauhdittui erityisesti 1980- ja 1990-luvuilla diskursiivisen käänteen myötä (ks. Fairclough 1989; 1992), kun tutkimuksissa kiinnostuttiin erityisesti tiedon ja vallan, subjektin ja identiteetin kysymyksistä (ks. esim. Grossberg 1995; Hall 1999). Samalla myös kielenkäytön kontekstualisointi nousi keskeiseksi.

Tällaisten erilaisten versioiden, variaatioiden ja keskinäisten suhteiden tarkastelu tuo mukaan myös kontekstisidonnaiset kulttuuriset käytänteet. Esimerkiksi kirjailija Salman Rushdie (1982, 8) on puhunut (englannin) kielen muuttamisen tärkeydestä jälkikoloniaalissa Intiassa ja muuallakin kolonialismista vapautuneessa maailmassa:

Uusissa itsenäistyneissä yhteiskunnissa kieli kuten niin paljon muutakin tarvitsee dekolonisointia. Se on muokattava uusin kuvin, jos me sen anglosaksisen kulttuuripiirin ulkopuoliset käyttäjät toivomme koskaan olevamme muita kuin taiteen setä-tuomoja.

Rushdie kuvaa dekolonisaatiota eli kolonialismin purkuprojektia uusien kuvien muokkaamiseksi, joka tapahtuu kielen kautta tai muuttamalla kieltä itseään. Tällaista prosessia hän pitää välttämättömänä, jotta uudessa tilanteessa ei vain jäljiteltäisi vanhaa vaan voitaisiin ilmaista jotain uutta ja omaa. Vastaavasti feministisessä kritiikissä on kiinnitetty huomiota kielenkäytön maskuliinisiin rakenteisiin ja käytänteisiin (Koivunen 1996, 47). Esimerkiksi ranskalainen filosofi Luce Irigaray (1996/1984, 153-154) on kiinnittänyt huomiota kieleen diskursiivisena verkkona, johon on kutoutunut sukupuolisuuden ulottuvuus, minkä "osoittaminen on melkoinen voimainkoitos, jonka tulokset sivuutetaan ankaran tieteellisestä perustelusta huolimatta".

Kuten tunnettu diskurssintutkija Norman Fairclough toteaa teoksessaan Language and power (1989), kielenkäyttö on osa sosiaalisia käytänteitä. Fairclough hyödyntää Michel Foucault'n ajatuksia pyrkimyksessään konkreti- 
soida kielen, vallan ja sosiaalisten käytänteiden välisiä suhteita. Myös Foucault (2005/1969, 68-69) asetti itselleen (ja implisiittisesti myös muille diskurssintutkijoille) tehtävän:

\begin{abstract}
Tehtävän, joka ei - enää - ole diskurssien kohtelemista merkkien (sisältöihin tai representaatioihin viittaavien merkitsevien elementtien) kokonaisuuksina vaan käytäntöinä, jotka muotoilevat järjestelmällisesti kohteet joista puhuvat. Tietenkin diskurssit on tehty merkeistä: mutta se, mitä ne tekevät, on enemmän kuin merkkien käyttämistä asioiden tarkoittamiseksi. Juuri tämä enemmän tekee niistä kieleen ja puheeseen palautumattomia. Juuri tämä 'enemmän' on saatava näkyviin ja kuvattava.
\end{abstract}

\title{
KIELELLISEN KÄÄNTEEN MERKITYS YHTEISKUNNALLISESSA JA HUMANISTISESSA TUTKIMUKSESSA
}

Yhteiskunnallisessa ja humanistisessa tutkimuksessa kielellinen käänne on tarkoittanut käytännössä tutkimuksellisen painopisteen muutosta positivistisesta tutkimusorientaatiosta kohti kvalitatiivisempaa tutkimusotetta. Kun aiemmin kritiikin kohteina olivat muun muassa tutkimuksen määrällisyys ja mekanistisuus sekä tutkimuksen objektiivisuuden harha, niin kielellinen käänne ja sen mukanaan tuomat tutkimukselliset viitekehykset tuntuivat tarjoavan tuoreen näkökulman tuottaa relevantteja tuloksia, jotka auttavat ymmärtämään niin käsitteiden historiallisuutta kuin kulttuuri- ja tilannesidonnaisuutta (Aro 2001, 32; Heiskala 2001, 35). Ne toivat myös lisävalaistusta tiedon syntymiseen ja muokkautumiseen sosiaalisissa prosesseissa, haastoivat tarkastelemaan itsestäänselvyyksiä kriittisesti sekä innoittivat pohtimaan sosiaalisen ja kielellisen toiminnan yhteyksiä.

Kielellinen käänne marssitti esiin nykyisin paljon käytetyt ideologian, representaation ja identiteetin käsitteet. Erityisesti 1970- ja 1980-luvuilla ideologia ja hegemonia olivat tutkimuksessa keskeisellä sijalla, kun taas 1990-luvulle siirryttäessä tutkijoiden mielenkiinto kohdistui erilaisten ilmiöiden, tapahtumien ja ryhmien representaatioihin ja identiteettien rakentumiseen esimerkiksi Internetissä, lehdistössä tai vaikkapa television saippuasarjoissa (ks. Sihvonen 2006, 129-130). Edelleenkin tutkijoiden vakiotyökaluihin kuuluva representaation käsite kuvaa erilaisia tapoja esittää ja kuvata maailmaa ympärillämme: asiat olisivat kuvattavissa, kerrottavissa ja sanottavissa toisin kuin jossain tietyssä kielenkäyttötilanteessa tehtiin (ks. esim. Pietikäinen \& Leppänen 2007). Esimerkiksi jokainen uutinen muodostuu lukemattomista valinnoista ja jokaisen valinnan kohdalla kuvaan astuu representaation politiikka ja siihen liittyvät kysymykset määrittely- ja puhevallasta (Pietikäinen 2000; Räisänen 2003). Journalistiikan tutkimuksessa representaatioiden tarkastelussa on käytetty paljon - laveasti sovellettua - Erving Goffmanin (1974, 10-11 \& 21-22) kehysanalyysiä (Väliverronen 1996, 107; Karvonen 2000, 79; Luhtakallio 2005; vrt. Puroila 2002, 24-25 \& 51). Kun yksittäisiä tapahtumia voi kielen konstruktivistisen luonteen mukaisesti kuvata lukuisista eri näkökulmista ja monilla eri tavoilla, tuodaan kussakin representaatiossa kuitenkin (enemmän tai vähemmän) korostuneesti esiin joitakin asioita ja jätetään sivuun toisia. Kielellisen

Tiedotustutkimus 2008:3 
käänteen hengessä kiinnostavaa onkin kysyä, miten tapahtuma kuvattiin ja mistä syystä juuri näin eikä toisella tapaa.

Toinen vakiokäsite kielellisen käänteen innoittamissa tutkimuksissa on identiteetti, jonka avulla pyritään löytämään vastauksia siihen, keitä olemme, mistä tulemme, minne kuulumme ja millaisiksi olemme tulossa. Kun identiteetit ymmärretään rakennetuiksi, nähdään esimerkiksi media yhdeksi tärkeäksi sosiaaliseksi tilaksi, jossa identiteettejä rakennetaan ja muutetaan. Tarjoamalla kuvia vaikkapa kansalaisuudesta, sukupuolesta ja etnisyydestä viestimet ovat mukana rakentamassa ymmärrystä identiteeteistä ja niiden välisistä eroista (Hall 1999; Pietikäinen 2003; ks. Valtonen 2000; Räisänen 2003).

Representaation ja identiteetin tarkastelun lisäksi kielellinen käänne johdatteli myös tutkimaan merkityksellistämisen prosesseja ja käytänteitä: miten esimerkiksi tieto ja tekstit muokkautuvat journalistisissa työkäytänteissä, keskellä mediatalouden reunaehtoja. Toisaalta mediatuotteiden kulttuuriset tulkinnat ja kuluttamisen käytänteet herättävät pohtimaan kysymyksiä yhteisöllisyydestä ja osallisuudesta.

Moneen tieteenalaan vaikuttavana käsitteenä kielellinen käänne on myös tuottanut tieteiden sisäisten ja välisten rajojen ja prioriteettien uudelleenjärjestelyjä. Samaan aikaan kun yhteiskuntatieteet lähentyivät kielentutkimusta, alkoi kielentutkimuksessa puolestaan näkyä aiempaa yhteiskunnallisempi ja sosiaalisempi tapa tutkia kielenkäyttöä. ${ }^{5}$ Kyse on jossain määrin käänteisestä ilmiöstä: siinä missä yhteiskuntatieteilijä on hakenut lisää tietoa kielestä todellisuuden rakentajana ja työkaluja sen analysoimiseen, on kielentutkija ottanut tutkimukseensa mukaan aiempaa laajemman sosiaalisen ja yhteiskunnallisen kontekstin. Teoreettisia ajatuksia tähän on haettu yhteiskuntatieteistä, filosofiasta ja kulttuurintutkimuksesta. Sekä yhteiskuntatieteissä että kielentutkimuksessa käänne tarkoitti kuitenkin samantyyppistä muutosta: etsittiin tapoja ymmärtää, tutkia ja teoretisoida kielen ja sosiaalisen todellisuuden välisiä suhteita. Taustalla vaikuttaa myös tieteenalojen pitkäaikainen tavoite yhdistää tutkimuksessa kielen ja yksilön mikrotaso ympäröivän tilanteen, ajan ja paikan makrorakenteisiin.

Esimerkkinä kielellisen käänteen vaikutuksesta tutkimukseen käy sosiolingvistiikka. Aiemmin siinä oli tapana tarkastella yhteiskuntaa lähinnä puhujiin liitettävinä muuttujina: puhetapojen eroja pyrittiin kuvaamaan sen mukaan, mikä oli puhujien asuin- tai syntymäpaikka, koulutus, ammatti, ikä tai sukupuoli; näkökulma oli etupäässä määrällinen eikä eroja pyritty selittämään ja tulkitsemaan muuttujien ulkopuolisella kontekstilla. Kieltä ei myöskään tarkasteltu tilanteisesti ja laadullisesti, joitakin poikkeuksia lukuun ottamatta. Kielellisen käänteen myötä tutkimuksessa otettiinkin etäisyyttä sekä kielen rakenteeseen keskittyvään että puhtaasti kuvailevaan sosiolingvistiseen tutkimukseen ja pyrittiin liittämään kielenkäyttö yhteiskunnalliseen todellisuuteen (esim. Wartiovaara 1991; Luukka 2003). ${ }^{6}$ Nykyään sosiolingvistiikan keskeisiä tutkimuskohteita ovat erilaiset kielen mikrotason ja yhteiskunnan makrotason risteymät, joissa voi yhtäaikaisesti tutkia kielen variaation ja käytön sosiaalisia reunaehtoja ja vaikutuksia. Tällaisia risteymiä ovat esimerkiksi mediaan ja monikielisyyteen liittyvät tutkimukset (Androutsopoulos 2006; Kelly-Holmes 2006).

Kielellinen käänne on vaikuttanut moniin lähestymistapoihin, joilla tuodaan yhteen kielen mikrotaso ja yhteiskunnallisen kontekstin makrotaso. Yksi näistä 
kielellisen käänteen merkkejä humanistisessa ja yhteiskunnallisessa tutkimuksessa. Diskurssintutkimuksen ja muun kielentutkimuksen teoreettisia ja metodisia lähestymistapoja on sovellettu ahkerasti tieteenalasta riippumatta. Kielellisen käänteen keskeiset lähestymistavat aineistoon, kuten diskurssianalyysi eri versioineen, keskustelunanalyysi, genreanalyysi, kertomustutkimus ja narratiivinen analyysi tuntuivat tarjoavan uutta terää muun muassa erilaisten mediaaineistojen tarkasteluun. Sisällönanalyysin, luokittelun ja lähiluvun sijaan ne mahdollistivat merkityksellistämisen prosesseiden tarkastelemisen. Kun tämä käytännössä tarkoitti yleensä siirtymistä määrällisestä tutkimuksesta laadulliseen, myös kontekstin rooli analyysin teossa korostui (ks. esim. Blommaert 2005; Väliverronen 2003, 15-16).

Kielellinen käänne onkin tutkimuksen teon käytännöissä näkynyt erityisesti erilaisten kielentutkimuksen perinteistä nousevien teoreettis-analyyttisten viitekehysten hyödyntämisenä. Tällaisia viitekehyksiä ovat tarjonneet muiden muassa argumentaatio- ja diskurssianalyysi. Lisäksi välineitä on haettu myös etnometodologisesta keskustelunanalyysista ja (lakoffilaisesta) metaforatutkimuksesta (ks. Lakoff \& Johnson 1980). Suosittua on ollut myös kriittinen diskurssintutkimus: esimerkiksi Faircloughin (1992) visuaalinen mallinnos kielenkäytön, diskursiivisten käytänteiden ja sosiaalisen kontekstin välisistä suhteista - tuttavallisesti "Faircloughin boksit" - on ollut eri alojen johdantokurssien perussisältöä, ja sitä on hyödynnetty hartaasti opinnäytetöissä kohta jo kahdenkymmenen vuoden ajan, vaikka tutkijoilla olisi käytettävissä paljon myös uudempaa alan tutkimusta (ks. esim. Blommaert 2005; Scollon 2007). Vaikka Faircloughin mallinnos on toki edelleen käyttökelpoinen osoittamaan yhden tavan yhdistää kielen mikrotason tarkastelu vuorovaikutuksellisin käytänteisiin ja yhteiskunnallisiin makrotason prosesseihin (soveltamisesta ja rajoituksesta ks. esim. Pietikäinen 2000), niin alan uudemmat suuntaukset ovat pyrkineet reagoimaan varhaisempaan kriittiseen diskurssintutkimukseen kohdistettuun kritiikkiin ja painottavatkin diskurssien situationaalista, historiallista ja kontekstisidonnaista ulottuvuutta ja variaatiota (ks. esim. Blommaert 2005; Pietikäinen ym. 2008) sekä yhdistävät diskursiivisen vallan tutkimukseen myös yksilön toiminnan ja kokemuksen tarkastelun (esim. Scollon \& Scollon 2004).

Kielellisen käänteen aloittama matka on jatkunut tekstien maisemista visuaalisuuden, kokemusten ja arjen maailmoihin. Kun tekstien hienosyisinkään analysointi ei aukaise kaikkia puolia merkityksen rakentumisesta eikä taltuta kokonaisuudessaan todellisuuden rakentumista, tärkeinä tutkimuskohteina esille ovat nousseet myös arki, toiminta ja kokemus. Tutkimuksellinen painopiste on nostanut tekstin ja diskurssien rinnalle etnografisempia otteita sekä toimintatutkimusta (Pietikäinen \& Dufva 2006; Scollon \& Scollon 2004).

Kielellisestä käänteestä vaikuttuneet tutkijat voivat tehdä tutkimusta hyvin monella tapaa. Kaikille yhteistä on kuitenkin sosiaalinen konstruktionismi, jonka voi ajatella toimivan erilaisten lähestymistapojen laajempana viitekehyksenä kulttuuristen, kielellisten tai diskursiivisten ilmiöiden tutkimisessa. Tällöin perusajatuksena on, että todellisuuden ajatellaan rakentuvan kielellisessä (ja muussa semioottisessa) vuorovaikutuksessa, ja näin - vuorovaikutuksen variaatiosta johtuen - myöskin todellisuudesta voidaan konstruoida useita eri versioita: elämästämme, tapahtumista ja tilanteista. Tämä tarkoittaa myös sitä, että käsitteet - myös kielelliseen käänteeseen liittyvät - ovat liikkeessä ja kiistanalaisia - sama "asia" ymmärretään eri tavoin eri paikoissa ja eri aikoina. ${ }^{7}$ 


\section{DIALOGEJA JA OHIPUHUMISIA KIELELLISEN KÄÄNTEEN JATKUMOLLA}

Kielellinen käänne on vauhdittanut keskustelua siitä, miten tutkia yksittäistä, uniikkia ja pientä kielenkäytön "palasta" osana laajempia kulttuurisia, historiallisia ja yhteiskunnallisia prosesseja, rakenteita ja muutoksia (Blommaert 2005). Esimerkiksi Fairclough (1992) puhuu vahvasti sen puolesta, kuinka kielenkäyttö on aina nähtävä osana sosiaalisia käytänteitä ja päinvastoin: sosiaalisten käytänteiden osa ovat myös kielelliset ja semioottiset käytänteet. Pyrkimyksenä on tavoittaa samanaikaisesti kielenkäytön mikrotaso ja laajemmat sosiaaliset ja yhteiskunnalliset makrotasot.

Tällaisella monitieteisellä tutkimuskentällä on erinomaiset mahdollisuudet niin hedelmällisiin dialogeihin kuin toistensa ohi puhumiseen. Parhaimmillaan esimerkiksi diskurssintutkimuksen teoreettisten ja analyyttisten viitekehysten hedelmällinen käyttö on johtanut uusiin kytköksiin käsitteiden, aineistojen ja kielenkäytön analysoimisen välille, toimiviin käsiteanalyyseihin ja refleksiivisiin pohdintoihin. Hyvänä esimerkkinä tästä on vaikkapa Jaana Vuoren (2001) sukupuolisuuden diskursseja tarkasteleva väitöskirja, jossa yhteiskunta- ja kielitieteellinen tapa käsitellä diskursseja ja kielenkäyttöä nivotaan koherentiksi kokonaisuudeksi.

Potentiaalinen ohipuhumisen paikka kielellisen käänteen innoittamien tutkijoiden välille voi syntyä perustavanlaatuisista eroista kielikäsityksissä. Ongelmia analyysissa syntyy etenkin silloin, jos kielikäsitys tutkimuksessa on positivistinen eikä kielellisen käänteen ydin - sosiaalinen rakentuminen - pysy analyysissa mukana. Pelkästään kielenkäyttöä silmäilemällä, luokittelemalla tai laskemalla ei tavoiteta kielenkäytön mikrotason prosesseja ja merkityksellistämisen tapoja. Jos ymmärrys kielestä konstruoivana ja sosiaalisena ilmiönä ohitetaan, analyysistä voi helposti tulla mekaanista ja kontekstin unohtavaa: tekstistä "luetaan ulos" tulkinta, ja unohdetaan, että teksti on itsessään maailma. Lisäksi konstruktivistisesta ajattelutavasta kumpuavia käsitteitä ja lähestymistapoja voidaan käyttää oman työn "pikapäivitykseen": omien, toisenlaisiin lähtökohtiin nojautuvien menetelmien päälle liimataan esimerkiksi diskurssintutkimuksen käsitteitä ja pyritään näin antamaan signaali, että tutkimus on kiinni kielellisen käänteen myötä tulleissa uusissa lähestymistavoissa ja sisällönanalyysit ja lähiluvut ovat taakse jäänyttä elämää. Jos kielen ja maailman dialektinen suhde ja kielen konstruoiva luonne jää tavoittamatta, seurauksena on helposti joiltakin osin yksinkertaistavia analyyseja.

Hajurakoa eri tutkimusperinteiden välille syntyy myös silloin, jos kielellinen käänne ja siitä vaikuttuneet tutkimusalat (muun muassa diskurssintutkimus) käsitetään yksin "metodisina" ja jätetään huomiotta teoreettiset taustasitoumukset, jotka liittyvät juuri kielen luonteeseen sosiaalista todellisuutta rakentavana ja jäsentävänä ja aina kontekstiinsa sidoksissa olevana resurssina. Esimerkiksi jotakin ilmiötä kuvaavia metaforia voi havaita ja poimia tekstistä, mutta silti ohittaa metaforateorian lähtökohdat: metaforat ovat perustavanlaatuinen tapa käsitteistää maailmaa ja metaforisuus merkitsee kielen kokonaisvaltaista metaforisuutta, ei vain pintatason (leksikaalista) metaforisuutta (esimerkiksi suomen paikallissijat ilmaisevat paitsi konkreettisia myös metaforisia suuntia ja tiloja; esim. Onikki 1998, 88-89; Mäntynen 2003, 136-137). ${ }^{8}$ Ongelmatonta ei myöskään ole eri perinteistä tai erilaisista kielikäsityksistä nousevien viite- 
alyysin perusajatus kontekstin rakentumisesta lokaalisesti keskustelussa sopii yhteen yhteiskunnallista kontekstia korostavan kriittisen diskurssintutkimuksen kanssa?

Sama pätee myös toisinpäin: pelkästään tekstianalyysillä tai tiettyä kieliopillista piirrettä tarkastelemalla ei tavoiteta kielen laajempaa yhteiskunnallista merkitystä ja kielenkäytön ja ympäröivän maailman välistä suhdetta. Monimutkaiset yhteiskunnalliset rakenteet ja muutokset eivät kiteydy yhteen - tai kahteenkaan - kielen piirteeseen. Esimerkiksi passiivi nousi keskeiseksi analyysin kohteeksi erityisesti kriittisen lingvistiikan myötä, ja sitä on ollut tapana käyttää esimerkkinä toimijoiden häivyttämisestä sekä näkökulman rajaamisesta teksteissä. Vaikka passiivi on kielellisenä valintana yksi kiinnostava piirre nimenomaan representaation ja toimijuuden kannalta, myös sen merkitys rakentuu kontekstissa ja sillä on esimerkiksi journalismissa myös muita merkityksiä (ks. Makkonen-Craig 2005). Funktionaalinen kielikäsitys tarkoittaa sitä, että analyysin lähtökohtana eivät ole kieliopilliset (rakenteelliset) kategoriat, kuten passiivi. Olennaista on, että toimijuutta ja sen puuttumista tai häivyttämistä voidaan ilmaista monella vaihtoehtoisella tavalla ja että kielellisillä muodoilla - myös passiivilla - on samanaikaisesti monia tehtäviä (kielen monifunktioisuus).

\section{MONIMUOTOINEN KIELI - TARKASTELUN KOHTEESTA TOIMINNAN RESURSSIKSI}

Kuten yllä on tullut ilmi, kielellinen käänne viittaa merkittävään tutkimukselliseen murrokseen, jonka seurauksena kieli on noussut tutkimuksen keskeiseksi kohteeksi ja kysymyksenasettelun lähtökohdaksi.Juuri tältä kannalta tärkeää on tiedostaa ja tuoda esiin, millaiseen kielikäsitykseen tutkimus kulloinkin pohjautuu. Se kun joka tapauksessa kulkee mukana, tutkijan tietämättäkin. Niin kielentutkimuksen kuin yhteiskuntatieteiden piiristä tulevalle tutkijalle yhteys kielen ja yhteiskunnan välillä ei ole suoraviivainen, vaan vaatii aina pohtimista ja monitieteisten aineksien pureskelemista.

Yksi kiinnostavista viimeaikaisista avauksista tässä keskustelussa on kielentutkimuksen puolella ollut ajatus kielestä sosiaalisen toiminnan resurssina (Blommaert 2005; Heller 2007; Pietikäinen ym. 2008). Tästä näkökulmasta katsottuna kieli ei ole erillinen, rajattu systeemi, vaan elastinen, dynaaminen, muuttuvainen resurssi, joka mahdollistaa ja rajoittaa toimintaa. Näkemyksen taustalla voi kuulla kaikuja myös dialogisesta kielifilosofiasta, joka korostaa kielen moniäänisyyttä ja heteroglossista luonnetta (ks. Dufva 2004; Pietikäinen \& Dufva 2006). Dialogisesti ajatellen kielenkäyttö on aina väistämättä heterogeenista ja muuttuvaa ja kantaa mukanaan aiempien käyttötilanteiden ja historian merkityksiä. Tämän dialogisuuden käsitteen avulla on mahdollista korostaa kielen tapahtumaluonnetta ja moniäänisyyttä. Kieli ei tässä näkemyksessä olekaan objekti vaan prosessi, joka on erottamaton osa sosiaalisen elämän muita prosesseja, ja kun kieli nähdään prosessina, solmitaan se tiiviisti osaksi sosiaalisten käytänteiden verkostoa. Tämä verkosto puolestaan mahdollistaa ja rajoittaa, motivoi ja lannistaa (siihen paikantuvien) kielellisten resurssien käyttöä.

Kieli voidaan ajatella resurssina, joka suhteutuu makrorakenteisin, ja tutkija voi tietyn tilanteen kielenkäyttöä yksityiskohtaisesti tarkastelemalla tut-

Tiedotustutkimus 2008:3 
kia niin kielenkäytön mikrotasoa kuin myös ympäröivän yhteiskunnan makrotasoa (Blommaert 2005). Tutkimuksessa tämä yksityiskohtainen analyysi avaa yhden näkökulman, jonka avulla voidaan pohtia, kuvata ja teoretisoida kielten huokoisia eroja ja rajoja, kielenkäyttäjän toimintaa ja valintoja, kielen kantamia valtarakenteita sekä kielenkäytön ja ympäröivän yhteiskunnan suhdetta. Kielen resurssiluonne mahdollistaa sen, että erilaiset humanistiset ja yhteiskuntatieteelliset tutkimusalat voivat todellisesti hyödyttää ja hyödyntää toisiaan. Viitteet

1 Sari Pietikäisen osalta artikkeli on osa Suomen Akatemian (2008-2011) rahoittamaa Pohjoinen Monikielisyys: diskurssit, käytänteet ja kokemukset kielellisestä monimuotoisuudesta Pohjois-Kalotilla -projektia (www.northernmultilingualism.fi).

2 Kielellisyyden eri ulottuvuuksista ks. Lehtonen (1996), erityisesti luku 3:"Kieli maailmassa olemisena."

3 Erilaisista suuntauksista ks. myös Vuori 2001, 80.

4 Tämä niin sanottu Sapirin ja Whorfin hypoteesikin on postuloitu konstruktio, sillä Edward Sapir ja Benjamin Whorf eivät koskaan yhdessä esittäneet sitä missään vaan se oli kummankin työssä läsnä toisistaan erillään.

5 Kielentutkimuksesta puhuessamme emme puhu homogeenisesta tutkimusalasta tai tutkijajoukosta.

6 Tästä muutoksesta ks. myös Kalliokoski 1996, 18-21.

7 Kielellisen käänteen pohtiminen nostaa esiin monitieteisen tutkimuksen peruskysymyksiä. Kielellinen käänne on nimittäin näkynyt muun muassa tutkimusten eklektisyytenä. Tämä eklektisyys on nähty toisinaan ongelmanakin sen mukaan, miltä tieteenalalta käsin asiaa on kommentoitu (esim. Palonen 1997, 3-4; Heikkinen \& Hiidenmaa 1999). Kun kullakin tieteenalalla on omat kysymyksenasettelunsa, päämääränsä ja kielikäsityksensä mutta viitekehykset osin samoja, saattaa toisen tapa tehdä päätelmiä tuntua esimerkiksi liian suoraviivaiselta tai jotenkin vajavaiselta (ks. esim. Väliverronen 2003, 27; Hellsten 2003, 76-78; myös Kalliokoski 1996, 21).

8 On huomattava, että esimerkiksi lakoffilainen metafora-analyysi liitetään nimenomaan kielentutkimuksen kognitiivisiin suuntauksiin ja että kognitiiviset ja funktionaaliset kielinäkemykset eroavat toisistaan; kognitiivisessa kielentutkimuksessa korostuu yleensä ajatus kielellisten konventioiden ohjailevasta vaikutuksesta (ks. Leino 2002/1991: 619-620). Kognitiivinen kielentutkimus ei siis ole samalla tapaa kiinnostunut kielenkäytön ja sosiaalisen todellisuuden suhteista kuin esim. diskurssintutkimus.

\section{Kirjallisuus}

Anderson, Benedict (2007/1991 [1983]) Kuvitellut yhteisöt: nationalismin alkuperän ja leviämisen tarkastelua. (Imagined communities.) Suom. Joel Kuortti. Tampere: Vastapaino.

Androutsopoulos, Jannis (2006) Multilingualism, diaspora, and the Internet: codes and identities on German-based diaspora websites. Journal of Sociolinguistics 10(4), 520-547.

Aro, Jari (2001) Retoriikka, refleksiivisyys ja sosiologia. Sosiologia, 38(1), 31-34.

Bakhtin [Bahtin], Mihail (1981) Dialogical imagination: Four essays. Toim. Michael Holquist. Käänt. Caryl Emerson \& Michael Holquist. Austin: University of Texas Press.

Barthes, Roland (1994/1957) Mytologioita. (Mythologies.) Suom. Panu Minkkinen. Helsinki: Gaudeamus. (Social construction of everyday life.) Suom. ja toim. Vesa Raiskila. Helsinki: Gaudeamus. 
Bergmann, Gustav (1950a) Logical positivism. Teoksessa Vergilius Ferm (toim.) A history of philosophical systems. New York: The Philosophical Library. 471-482.

Bergmann, Gustav (1950b) Semantics. Teoksessa Vergilius Ferm (toim.) A history of philosophical systems. New York: The Philosophical Library. 483-492.

Bergmann, Gustav (1959) Preface. Teoksessa Gustav Bergmann, Meaning and existence. Madison: University of Wisconsin Press. $\mathrm{v}-\mathrm{x}$.

Bergmann, Gustav (1964) Logic and reality. Madison: University of Wisconsin Press.

Blommaert, Jan (2005) Discourse: A critical introduction. Cambridge: Cambridge University Press.

Chomsky, Noam (1957) Syntactic structures. s-Gravenhage: Mouton.

Dallmayr, Fred R. \& Thomas A. McCarthy (1977) Introduction. Teoksessa Dallmayr \& McCarthy (toim.) Understanding and social inquiry. Notre Dame: University of Notre Dame Press. 1-15.

Derrida, Jacques (1978/1967) Of grammatology. (De la grammatologie.) Käänt. Gayatri Chakravorty Spivak. 3. painos. Baltimore \& London: Johns Hopkins University Press.

Dufva, Hannele (2004). Language, thinking and embodiment. Teoksessa Bostad F; C. Brandist; L. S. Evensenet \& H. C. Faber (toim.) Bakhtinian perspectives on language and culture: Meaning in language, art and new media. Basingstoke: Palgrave Macmillan. 133-146.

Fairclough, Norman (1989) Language and power. London: Longman.

Fairclough, Norman (1992) Discourse and social change. Cambridge: Polity Press.

Fish, Stanley (1980) Is there a text in this class? The authority of interpretive communities. Cambridge: Harvard University Press.

Foucault, Michel (2005/1969) Tiedon arkeologia. (Larcheologie du savoir.) Suom. Tapani Kilpeläinen. Tampere: Vastapaino.

Garfinkel, Harold (1967) Studies in ethnomethodology. Englewood Cliffs: Prentice-Hall.

Genette, Gérard (1966-1972) Figures I-III. Paris: Éditions du Seuil.

Goffman, Erving (1974) Frame analysis: An essay on the organization of experience. Cambridge: Harvard University Press.

Grossberg, Lawrence (1995) Mielihyvän kytkennät: Risteilyjä populaarikulttuurissa. Toim. \& suom. Lehtonen, Mikko; Juha Koivisto; Ensio Puoskari \& Timo Uusitupa. Tampere: Vastapaino.

Hall, Stuart (1992/1986) Postmodernismista ja artikulaatiosta. (On postmodernism and articulation: An interview with Stuart Hall.) Haast. Lawrence Grossberg. Suom. Veikko Pietilä. Teoksessa Hall, Stuart: Kulttuurin ja politiikan murroksia. Tampere: Vastapaino.

Hall, Stuart (1999) Identiteetti. Suom. ja toim. Lehtonen, Mikko \& Juha Herkman. Tampere: Vastapaino.

Halliday, M. A. K. (1973) Explorations in the functions of language. London: Edward Arnold.

Heikkinen, Vesa \& Pirjo Hiidenmaa (1999) Me ja muut tekstintutkijat. Virittäjä 103(1), 84-92.

Heiskala, Risto (2001) Kulttuurinen konstruktionismi ja yhteiskunnalliset pakot. Sosiologia $38(1), 35-42$.

Heller, Monica (2007) Bilingualism as ideology and practice. Teoksessa Monica Heller (toim.) Bilingualism: A social approach. Basinstoke: Palgrave. 1-24.

Hellsten, Iina (2003) Monistettu Dolly. Johdatusta metafora-analyysiin. Teoksessa Kantola, Anu; Inka Moring \& Esa Väliverronen (toim.) Media-analyysi: Tekstistä tulkintaan. Helsinki: Palmenia-kustannus. 4-19.

Iggers, Georg G. (2005/1997) The 'linguistic turn': The end of history as a scholarly discipline. Teoksessa Georg G. Iggers, Historiography in the twentieth-century: From scientific objectivity to the postmodern challenge. Uud. lait. Middletown: Wesleyan University Press. $118-133$ \& $168-170$.

Irigaray, Luce (1996/1984) Sukupuolieron etiikka. (Éthique de la différence sexuelle.) Suom. Pia Sivenius. Helsinki: Gaudeamus.

Ive, Peter (1999) Gramsci and the so-called 'linguistic turn' (A discussion and dissertation abstract). International Gramsci Society Newsletter (9), 42-45. <www. internationalgramscisociety.org/igsn/articles/a09_12.shtml> (7.12.2007).

Kalliokoski, Jyrki (1996) Johdanto. Teoksessa Kalliokoski, Jyrki (toim.) Teksti ja ideologia: Kirjoituksia kielestä ja vallasta julkisessa kielenkäytössä. Kieli 9. Helsinki: Helsingin yliopiston suomen kielen laitos. 8-36.

Karvonen, Erkki (2000) Tulkintakehys (frame) ja kehystäminen. Tiedotustutkimus 2, 78-84. 
Kelly-Holmes, Helen (2006) Multilingualism and commercial language practices on the Internet. Journal of Sociolinguistics 10(4), 507-519.

Koivunen, Anu (1996) Sorto. Teoksessa Koivunen, Anu \& Marianne Liljeström (toim.) Avainsanat: 10 askelta feministiseen tutkimukseen. Tampere: Vastapaino. 35-76.

Kristeva, Julia (1992/1988) Muukalaisia itsellemme. (Etrangers à nous-mêmes.) Suom. Päivi Malinen. Helsinki: Gaudeamus.

Kuortti, Joel (1998) Fictions to live in: Narration as an argument for fiction in Salman Rushdie's novels. Frankfurt am Main: Peter Lang.

Lakoff, George \& Mark Johnson (1980) Metaphors we live by. Chicago: Chicago University Press.

Lehtonen, Mikko (1996) Merkitysten maailma. Tampere: Vastapaino.

Leino, Pentti (2002/1987) Kieli ja maailman hahmottaminen. Teoksessa Tainio, Liisa; Aki Ontermaa; Tapani Kelomäki \& Minna Jaakola (toim.) Mittoja, muotoja, merkityksiä. Helsinki: Suomalaisen Kirjallisuuden Seura. 519-548.

Leino, Pentti (2002/1991) Inhimillinen reaktio. Teoksessa Tainio, Liisa; Aki Ontermaa; Tapani Kelomäki \& Minna Jaakola (toim.) Mittoja, muotoja, merkityksiä. Helsinki: Suomalaisen Kirjallisuuden Seura. 608-621.

Luhtakallio, Eeva (2005) Kehysanalyysi mediakuvien sukupuolirepresentaatioiden tutkimuksessa. Sosiologia 42(3), 189-206.

Luukka, Minna-Riitta (2003) Kelpaanko tällaisena? Tyttöyden rakentuminen Demi-lehden palstoilla. Teoksessa Modinos, Tuija \& Annika Suoninen (toim.) Merkillinen media: Tekstit nuorten arjessa. Jyväskylä: Jyväskylän yliopisto, Soveltavan kielentutkimuksen keskus. 17-38.

Lyons, John (1977) Semantics. Cambridge: Cambridge University Press.

Makkonen-Craig, Henna (2005) Toimittajan läsnäolo sanomalehtitekstissä. Näkökulmia suomen kielen dialogisiin passiivilauseisiin. Helsinki: Suomalaisen Kirjallisuuden Seura.

Mäntynen, Anne (2003) Miten kielestä kerrotaan. Kielijuttujen retoriikkaa. Helsinki: Suomalaisen Kirjallisuuden Seura.

Norris, Christopher [C. N.] (1995) Linguistic turn, The. Teoksessa Honderich, Ted (toim.) The Oxford companion to philosophy. Oxford: Oxford University Press. 492.

Onikki, Tiina (1998) Kieli ja ajattelu. Kielen maailmankuvasta sen sisäisiin näkökulmaeroihin. Teoksessa Kivikuru, Ullamaija \& Risto Kunelius (toim.) Viestinnän jäljillä. Näkökulmia uuden ajan ilmiöön. Helsinki: WSOY.79-98.

Palonen, Kari (1997) Kootut retoriikat: Esimerkkejä politiikan luennasta. SoPhi. Yhteiskuntatieteiden, valtio-opin ja filosofian julkaisuja, 11. Jyväskylä: Jyväskylän yliopisto.

Peirce, Charles S. (2001) Johdatus tieteen logiikkaan ja muita kirjoituksia. Valinnut ja suom. Markus Lång. Tampere: Vastapaino.

Pietikäinen, Sari (2000) Discourses of differentiation: Ethnic representations in newspaper texts. Jyväskylä Studies in Communication 12. Jyväskylä: University of Jyväskylä.

Pietikäinen, Sari (2003) Indigenous identity in print. Discourse E Society 14(5), 581-609.

Pietikäinen, Sari \& Hannele Dufva (2006) Voices in discourses: Dialogism, critical discourse analysis and ethnic identity. Journal of Sociolinguistics 10(2), 205-224.

Pietikäinen, Sari \& Sirpa Leppänen (2007) Saamelaiset toisin sanoin. Teoksessa Kuortti, Joel; Mikko Lehtonen \& Olli Löytty (toim.) Kolonialismin jäljet: Perifeerisyys ja Suomi. Helsinki: Gaudeamus. 231-248.

Pietikäinen, Sari, Riikka Alanen, Hannele Dufva, Paula Kalaja, Sirpa Leppänen \& Anne Pitkänen-Huhta (2008, painossa) Languaging in Ultima Thule: Multilingualism in the life of a Sami boy. International Journal of Multilingualism.

Puroila, Anna-Maija (2002) Kobtaamisia päiväkotiarjessa: Kebysanalyyttinen näkökulma varhaiskasvatustyöhön. Oulu: Oulun yliopisto, 2002. Acta Universitatis Ouluensis Scientiae Rerum Socialium, E 51. <http://herkules.oulu.fi/isbn9514266501/isbn9514266501.pdf >.

Rorty, Richard (1967) Introduction: Metaphilosophical difficulties of linguistic philosophy. Teoksessa Rorty, Richard (toim.) The linguistic turn: Essays in philosophical method. Chicago: University of Chicago Press. 1-39.

Rorty, Richard (toim.) (1967) The linguistic turn: Essays in philosophical method. Chicago: University of Chicago Press.

Rorty, Richard (1999) Philosophy and social hope. London: Penguin.

Rushdie, Salman (1982) The Empire writes back with a vengeance. The Times (July 3), 8. 
Räisänen, Ulla (2003) Masentuneet nuoret mediassa: Riskiryhmiä ja masennuksen orjia. Teoksessa Modinos, Tuija \& Annika Suoninen (toim.) Merkillinen media: Tekstit nuorten arjessa. Jyväskylä: Jyväskylän yliopisto, Soveltavan kielentutkimuksen keskus. 39-63.

Sacks, Harvey (1992). Lectures on conversation [1964-1968], vol. 1. Cambridge: Blackwell Publishers.

Said, Edward W. (1978) Orientalism: Western conceptions of the Orient. London: Routledge and Kegan Paul.

de Saussure, Ferdinand (1916) Course de linguistique génerale. Toim. Bally, Charles \& Albert Sechehaye. Paris: Payot.

Scollon, Ron \& Suzie Wong Scollon (2004) Nexus analysis: Discourse and the emerging Internet. London: Routledge.

Scollon, Ron (2007) Analysing public discourse: discourse analysis in the making of public policy. London: Routledge.

Searle, John R. (1969) Speech acts: An essay in the philosophy of language. Cambridge: Cambridge University Press.

Sihvonen, Tanja (2006) Representaatio/simulaatio: Esityksestä toimintaan ja takaisin. Teoksessa Ridell, Seija; Pasi Väliaho \& Tanja Sihvonen (toim.) Mediaa käsittämässä. Tampere: Vastapaino. 129-152.

Šklovski, Viktor (2001/1917) Taiteesta - keinona. Teoksessa Pesonen, Pekka \& Timo Suni (toim.) Venäläinen formalismi: Antologia. Helsinki: Suomalaisen Kirjallisuuden Seura.

Spivak, Gayatri Chakravorty (1987) In other worlds: Essays in cultural politics. London: Methuen.

Tompkins, Jane P. (1980) Reader-response criticism. Baltimore: Johns Hopkins University Press.

Valtonen, Sanna (2000) Mikä suomalaisissa on vikana? Tapaustutkimus työttömyys-aiheisten kirjoitusten kansallisesta ulottuvuudesta. Teoksessa Tapper, Helena (toim.) Me median maisemissa: reflektioita identiteettiin ja mediaan. Oppimateriaaleja, Helsingin yliopiston tutkimus- ja koulutuskeskus Palmenia. Helsinki: Palmenia. 51-79.

Wartiovaara, Katarina (1991) Uutinenko neutraali? Lingvistinen analyysi Tupolev-uutisten ideologisista rakenteista. Teoksessa Holli, Anne Maria \& Katarina Wartiovaara (toim.) Kortti puhuu: Selvityksiä Tupolev-keskustelusta. Helsinki: Sosiaali- ja terveysministeriön Tasaarvojulkaisuja, sarja A:1/1991.49-99.

Wittgenstein, Ludwig (1984/1922) Tractatus logico-philosophicus eli loogis-filosofinen tutkielma. Suom. Heikki Nyman. 3, tark. painos. Porvoo: Söderström.

Wittgenstein, Ludwig (1999/1953) Filosofisia tutkimuksia. (Philosophische Untersuchungen). Suom. Heikki Nyman. Taskutieto 155. 2. p. Porvoo: WSOY.

Vuori, Jaana (2001) Äidit, isät ja ammattilaiset: Sukupuoli, toisto ja muunnelmat asiantuntijoiden kirjoituksissa. Acta Electronica Universitatis Tamperensis 95. Tampere: Tampere University Press. <http://acta.uta.fi/pdf/951-44-5065-5.pdf>.

Väliverronen, Esa (1996) Ympäristöuhan anatomia: Tiede, mediat ja metsän sairaskertomus. Tampere: Vastapaino.

Väliverronen, Esa (2003) Mediatekstistä tulkintaan. Teoksessa Kantola, Anu; Inka Moring \& Esa Väliverronen (toim.) Media-analyysi: Tekstistä tulkintaan. Helsinki: Palmenia-kustannus. $13-39$. 